\title{
Synthesis, Anthelmintic and Anti-inflammatory Activities of Some Novel Imidazothiazole Sulfides and Sulfones
}

\author{
Nitinkumar S. Shetty, ${ }^{*}$ Imtiyaz Ahmed M. Khazi, ${ }^{\dagger}$ and Chuljin Ahn \\ Department of Chemistry, Changwon National University, Changwon 641-773, Korea. *E-mail: snitinshetty@gmail.com \\ ${ }^{\dagger}$ Department of Chemistry, Karnatak University, Dharwad-580 003, India \\ Received March 2, 2010, Accepted June 30, 2010
}

\begin{abstract}
A series of new 6-aryl-3-(3,4-dimethoxy-phenyl)-2-phenylsulfanyl-imidazo[2,1-b]-thiazole (5a-c) and 6-aryl-2benzenesulfonyl-3-(3,4-dimethoxy-phenyl)imidazo[2,1-b]- thiazole (6a-c) have been prepared and characterized by analytical and spectral methods. The title compounds 5a-c and 6a-c were obtained by the reaction of 4-(3,4dimethoxy-phenyl)-5-phenylsulfanyl-thiazol-2-ylamine (3) and 5-benzenesulfonyl-4-(3,4-dimethoxy -phenyl)thiazol2-ylamine (4) with various phenacyl bromides in anhydrous ethanol. These newly synthesized compounds (5a-c and 6a-c) were screened for their anthelmintic and anti-inflammatory activities, where they have displayed better activities.
\end{abstract}

Key Words: Imidazo[2,1-b]thiazole, Sulfides, Sulfones, Anthelmintic activity, Anti-inflammatory activity

\section{Introduction}

A lot of work on the synthesis and biological activities of the condensed imidazo[2,1-b]-thiazoles has been reported since the discovery of novel broad spectrum anthelmintic, tetramisole. ${ }^{1}$ It is interesting to note that not a single drug better than tetramisole has been evaluated till now among the derivatives of imidazo[2,1- $b]$ thiazoles. Imidazothiazole derivatives have been shown to display potent antitumor and fungistatic activities. ${ }^{2-5}$ In continuation of our work on nitrogen containing bridgehead heterocycles, ${ }^{6-8}$ herein we report synthesis of sulfides and sulfones of thiazoloimidazoles expecting them to exhibit better anthelmintic and anti-inflammatory properties.

\section{Results and Discussion}

The synthetic pathway for the preparation of the title compounds is depicted in Scheme 1.

5-Bromo-4-(3,4-dimethoxy-phenyl)thiazol-2-ylamine (2) was obtained by the bromination of 4-(3,4-dimethoxy-phenyl) thiazol-2-ylamine (1). ${ }^{9}$ Nucleophilic displacement reaction of 5-bromo-4-(3,4-dimethoxy-phenyl)thiazol-2-ylamine (2) with an appropriate thiophenoxide anion resulted in the formation of 4-(3,4-dimethoxy-phenyl)-5-phenylsulfanyl-thiazol-2-ylamine (3). Oxidation of the sulfide (3) with hydrogen peroxide gave the respective sulfone (4). The imidazothiazole ring was synthesized by adopting the $3+2$ approach wherein the nucleo-

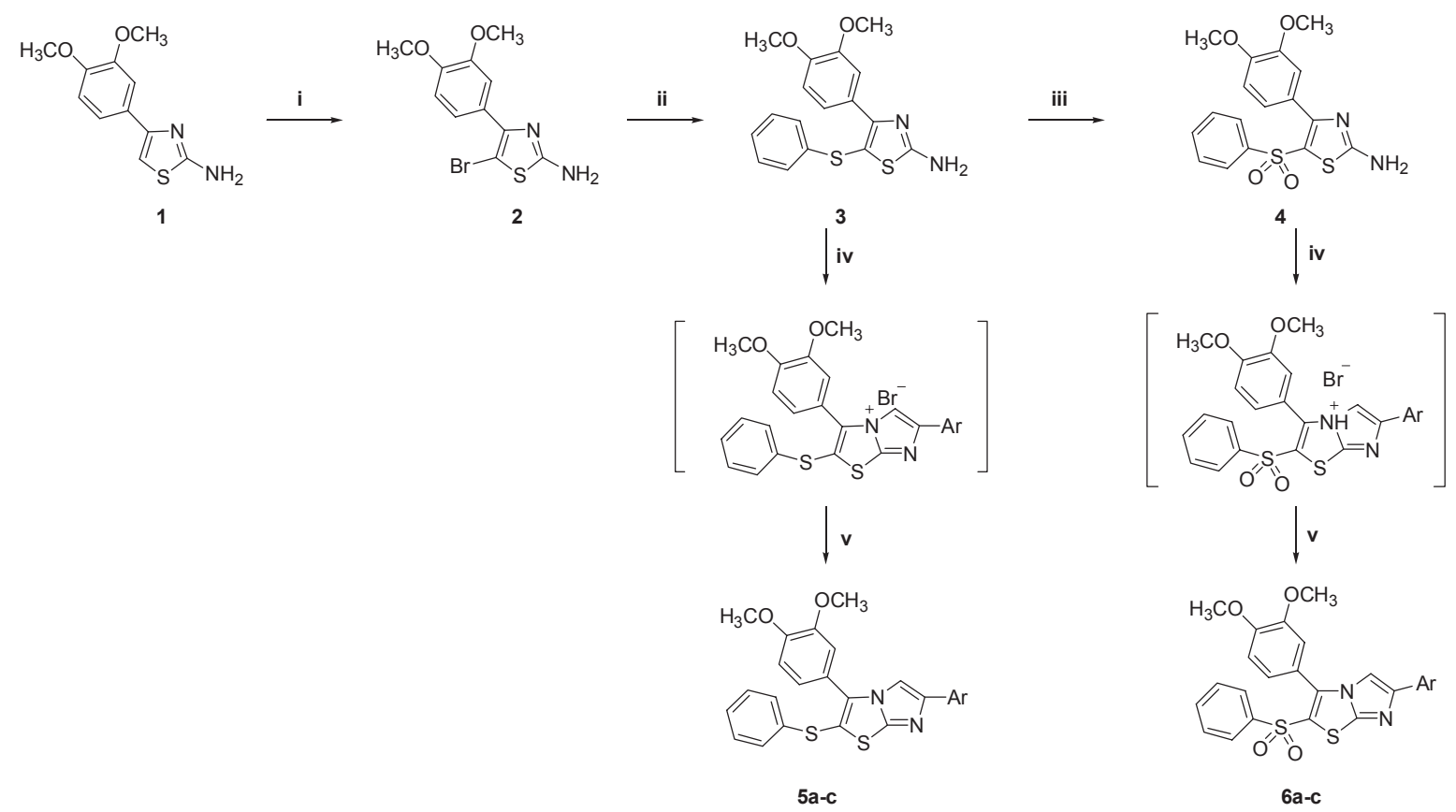

i. $\mathrm{Br}_{2} / \mathrm{AcOH}$, ii. ArSNa, Ethanol, Reflux 5h, iii. $\mathrm{H}_{2} \mathrm{O}_{2}, \mathrm{AcOH}$, rt, 48h, iv. $\mathrm{ArCOCH} \mathrm{H}_{2} \mathrm{Br}$, Ethanol, Reflux 12h., v. Aq. $\mathrm{Na}_{2} \mathrm{CO}_{3}$. a, $\mathrm{Ar}=p-\mathrm{Br} \mathrm{Ph} ; \mathbf{b}, \mathrm{Ar}=p-\mathrm{Cl} \mathrm{Ph} ; \mathbf{c}, \mathrm{Ar}=\mathrm{NO}_{2} \mathrm{Ph}$. 
Table 1. Anthelmintic activities

\begin{tabular}{cccc}
\hline Compd. No. & $\begin{array}{c}\text { Concentration } \\
\%(\mathrm{w} / \mathrm{v})\end{array}$ & $\begin{array}{c}\text { Paralysis time } \\
\text { in minutes }\end{array}$ & $\begin{array}{c}\text { Death time } \\
\text { in minutes }\end{array}$ \\
\hline 5a & $\mathbf{2 . 5}$ & $\mathbf{4 2}$ & $\mathbf{6 9}$ \\
$5 \mathrm{~b}$ & $\mathbf{1 . 0}$ & $\mathbf{3 8}$ & $\mathbf{8 0}$ \\
& 2.5 & 57 & 83 \\
$5 \mathrm{c}$ & 1.0 & 42 & 95 \\
\hline & 2.5 & 74 & 150 \\
6a & 1.0 & 89 & 175 \\
& $\mathbf{2 . 5}$ & $\mathbf{3 8}$ & $\mathbf{5 8}$ \\
6b & $\mathbf{1 . 0}$ & $\mathbf{2 6}$ & $\mathbf{6 5}$ \\
\hline 6c & 2.5 & 44 & 119 \\
& 1.0 & 52 & 127 \\
\hline 1\%gum acacia & $\mathbf{2 . 5}$ & $\mathbf{4 0}$ & $\mathbf{6 6}$ \\
(control) & - & $\mathbf{3 0}$ & $\mathbf{7 8}$ \\
\hline Piperazine & 1.0 & - & - \\
Citrate & & 21 & 72 \\
\hline
\end{tabular}

philic sites from the thiazole nucleus and electrophilic sites from $\alpha$-haloketones were utilized. Thus, condensation of 4-(3,4-dimethoxy-phenyl)-5-phenylsulfanyl-thiazol-2-ylamine (3) and its sulfone (4) with phenacyl bromides yielded the hydrobromide salts of imidazothiazole derivatives, which on neutralization with aqueous sodium carbonate gave the required free bases (5a-c and 6a-c). The structures of all these newly synthesized 6-aryl-3-(3,4-dimethoxy-phenyl)-2-phenylsulfanyl-imidazo $[2,1-b]$ thiazole (5a-c) and 6-aryl-2-benzene sulfonyl-3-(3,4dimethoxy-phenyl)imidazo[2,1-b]thiazole (6a-c) were established by analytical and spectroscopic methods. UV spectral data of 6a-c revealed the presence of two absorption bands, one in the region of $274-283 \mathrm{~nm}$ and other at $304-319 \mathrm{~nm}$. These bands are due to $n-\pi *$ transition pertaining to $S=O$ group which were found to undergo hypsochromic shift with increase in solvent polarity. IR spectra of 6a-c shows bands at 1535 $(\mathrm{C}=\mathrm{N}), 1329$ (asym), and 1180 (sym) $(\mathrm{S}=\mathrm{O}$ of sulfone $) \mathrm{cm}^{-1}$.

The results of anthelmintic activity screening (Tables 1$)$ revealed that both 6-aryl-3-(3,4-dimethoxy-phenyl)-2-phenylsulfanyl-imidazo[2,1-b]thiazole (5a-c) and 6-aryl-2-benzenesulfonyl-3-(3,4-dimethoxy-phenyl)imidazo[2,1-b]thiazole (6a-c) displayed good anthelmintic activity. It is observed that 2-arenesulfonyl derivatives (6) exhibited better anthelmintic activities compared with their arylthio counterparts (5) which can be attributed to the presence of a better pharmacophoric sulfonyl group. Similarly, anti-inflammatory activity screening (Table 2) shows that 2-arenesulfonyl derivatives (6) exhibited better anti-inflammatory activities compared with their arylthio counterparts (5).

\section{Biological Activity}

\section{Anthelmintic activity.}

Materials and methods: All the chemicals were used of IP/BP specifications. Earthworms (pheritima postuma) of same size were used for evaluating anthelmentic activity using piperzine
Table 2. Anti-inflammatory activities

\begin{tabular}{ccc}
\hline & \multicolumn{2}{c}{$\%$ Inhibition of edema } \\
\cline { 2 - 3 } Compd. No. & Oral (po) & Oral (po) \\
& $2 \mathrm{~h}$ & $3 \mathrm{~h}$ \\
\hline $5 \mathrm{a}$ & 25 & 21 \\
$5 \mathrm{~b}$ & 13 & 17 \\
$5 \mathrm{c}$ & 30 & 31 \\
$\mathbf{6 a}$ & $\mathbf{4 0}$ & $\mathbf{4 8}$ \\
$\mathbf{6 b}$ & $\mathbf{3 5}$ & $\mathbf{3 7}$ \\
$6 \mathrm{c}$ & 32 & 30 \\
Phenyl butazone & 60 & 65 \\
\hline
\end{tabular}

citrate, as a standard following the method described by Kakrani and Kalyani. ${ }^{10}$ A suspension of $2.5 \%(\mathrm{w} / \mathrm{v})$ and $1 \%(\mathrm{w} / \mathrm{v})$ of test compounds were prepared in $1 \%(\mathrm{w} / \mathrm{v})$ of gum acacia. A standard solution of $1.0 \%(\mathrm{w} / \mathrm{v})$ of piperzine citrate was prepared in $1 \%(\mathrm{w} / \mathrm{v})$ gum acacia. Six worms of approximately same size were placed in each petridish containing $50 \mathrm{~mL}$ of the suspension of the test compounds and standard drug at the above mentioned concentration. The control test having six worms in $50 \mathrm{~mL}$ of $1 \%(\mathrm{w} / \mathrm{v})$ of gum-acacia solution was also carried out simultaneously. The average time required for the paralysis and death of worms was recorded. The paralysis time of worms was the time when the worms show no movement after the drug administration but become active on transferring them into a beaker containing hot water at $40{ }^{\circ} \mathrm{C}$. The death of worms was ascertained by the absence of movements of the worms in hot water. The results are given in Table 1.

Anti-inflammatory activity.

Materials and methods: The anti- inflammatory activity was studied as per the method described by Winter ${ }^{11}$ et al. The albinorats $(100-150 \mathrm{~g})$ were divided into 10 groups each consisting of six animals. First group received solvent control $(0.5 \mathrm{~mL}, 1 \%$ CMC) orally, next eight groups received the test compounds (200 mg/kg b.w) and the last group received phenylbutazone $(150 \mathrm{mg} / \mathrm{kg}$ b.w). Inflammation was induced after 30 minutes of drug administration by injecting carregenin $(0.05 \mathrm{~mL}$ of $1 \%$ solution) into the sub-planter tissue of the left hind paw in each rat. Then the volume of hind paw was measured by platismograph at $0 \mathrm{hr}$ and $3 \mathrm{hr}$. The percentage reduction of edema was calculated as follows:

$$
\% \text { inhibition }=100\left(1-\mathrm{V}_{\mathrm{t}} / \mathrm{V}_{\mathrm{c}}\right)
$$

Where $\mathrm{V}_{\mathrm{t}}=$ Increase in volume of paw edema of treated animals. $V_{c}=$ Increase in paw edema of control. The results are presented in Table 2.

\section{Experimental Section}

5-Bromo-4-(3,4-dimethoxy-phenyl)thiazol-2-ylamine (2). To an ice cold solution of 4-(3,4-dimethoxy-phenyl)thiazol-2ylamine (1) (0.1 mole) in glacial acetic acid (30 mL), a solution of bromine $(5 \mathrm{~mL}, 0.1$ mole) in acetic acid $(10 \mathrm{~mL})$ was added at $5-10^{\circ} \mathrm{C}$ drop by drop during 30 minutes. It was further stirred at room temperature for $2 \mathrm{hrs}$ and cooled in an ice bath. 
The solid that separated was collected by filtration, washed with ice cold acetic acid $(2 \mathrm{~mL})$ and dried. It was then suspended in ice cold water and basified by ammonia solution to obtain free base. The acidic filtrate was cooled and basified when a small quantity of the base was obtained. It was combined with the main product and purified by recrystallisation from aqueous ethanol, pale yellow needles, Yield $70 \%$, mp $128-130{ }^{\circ} \mathrm{C}$; IR (KBr) $v \mathrm{~cm}^{-1}$ 3376, 3234, 2909; ${ }^{1} \mathrm{H}$ NMR (300 MHz, $\left.\mathrm{CDCl}_{3}\right) \delta 3.94$ (s, $\left.6 \mathrm{H}, \mathrm{OCH}_{3}\right), 5.21\left(\mathrm{~s}, 2 \mathrm{H}, \mathrm{NH}_{2}\right.$ exchangeable with $\left.\mathrm{D}_{2} \mathrm{O}\right), 6.90$ (d, $1 \mathrm{H}, J=8.3, \mathrm{ArH}), 7.41-7.47$ (m, 2H, ArH). Anal. calcd. for $\mathrm{C}_{11} \mathrm{H}_{11} \mathrm{BrN}_{2} \mathrm{O}_{2} \mathrm{~S}$ : C, 41.92; H, 3.52; N, 8.89. Found: C, 41.99; $\mathrm{H}, 3.42 ; \mathrm{N}, 8.98 \%$.

4-(3,4-Dimethoxy-phenyl)-5-phenylsulfanyl-thiazol-2-ylamine (3). Thiophenol (11.0 g, 0.1 mole) in ethanol was added to a solution of sodium ethoxide (prepared from ethanol and metallic sodium) (2.3 g, 0.1 mole) with stirring at room temperature during 30 minutes. A solution of 5-bromo-4-(3,4-dimethoxy-phenyl)thiazol-2-ylamine (2) (0.1 mole) in ethanol was then added to this reaction mixture and it was refluxed for $5 \mathrm{hrs}$. The solvent was removed and the residue added to crushed ice (200 g). A solid that separated was collected by filtration and purified by crystallization from ethanol followed by column chromatography over neutral alumina using a mixture of benzene and chloroform $(90: 10 \mathrm{v} / \mathrm{v})$ as eluent. Evaporation of the six first fractions gave a pure product, which showed a single spot on TLC plate. Yield $65 \%$, mp $150-152^{\circ} \mathrm{C}$; IR $(\mathrm{KBr}) v \mathrm{~cm}^{-1}$ $3367,3249,1628,1530 ;{ }^{1} \mathrm{H}$ NMR $\left(300 \mathrm{MHz}, \mathrm{CDCl}_{3}\right) \delta 3.90$ (s, $\left.6 \mathrm{H}, \mathrm{OCH}_{3}\right), 4.84$ (s, 2H, $\mathrm{NH}_{2}$ exchangeable with $\mathrm{D}_{2} \mathrm{O}$ ), 6.867.52 (m, 8H, ArH). Anal. calcd. for $\mathrm{C}_{17} \mathrm{H}_{16} \mathrm{~N}_{2} \mathrm{O}_{2} \mathrm{~S}_{2}$ : C, 59.28; $\mathrm{H}$, 4.68; N, 8.13. Found: C, 59.36; H, 4.50; N, 8.23\%.

5-Benzenesulfonyl-4-(3,4-dimethoxy-phenyl)thiazol-2-ylamine (4). To a solution of 4-(3,4-dimethoxy-phenyl)-5-phenylsulfanyl-thiazol-2-ylamine (3) (0.1 mole) in a minimum quantity of glacial acetic acid, was added hydrogen peroxide $(6 \mathrm{~mL}$, $30 \%$ ) and the mixture stirred at room temperature for $48 \mathrm{hrs}$ with the intermittent addition of hydrogen peroxide $(1 \mathrm{~mL})$ at every $12 \mathrm{hrs}$. A solid that separated was collected by filtration and purified by crystallization from alcohol. Yield $60 \%, \mathrm{mp}$ 172 - $174{ }^{\circ} \mathrm{C}$; IR (KBr) vcm ${ }^{-1} 3373,3228,1322,1139 ;{ }^{1} \mathrm{H}$ NMR $\left(300 \mathrm{MHz} \mathrm{CDCl}_{3}\right) \delta 3.90\left(\mathrm{~s}, 6 \mathrm{H}, \mathrm{OCH}_{3}\right), 5.02\left(\mathrm{~s}, 2 \mathrm{H}, \mathrm{NH}_{2} \mathrm{ex}-\right.$ changeable with $\left.\mathrm{D}_{2} \mathrm{O}\right), 6.82-7.56(\mathrm{~m}, 8 \mathrm{H}, \mathrm{ArH})$. Anal. calcd. for $\mathrm{C}_{17} \mathrm{H}_{16} \mathrm{~N}_{2} \mathrm{O}_{4} \mathrm{~S}_{2}$ : C, 54.24; H, 4.28; N, 7.44. Found: C, 54.35; $\mathrm{H}, 4.20 ; \mathrm{N}, 7.49 \%$.

6-(p-Bromo-phenyl)-3-(3,4-dimethoxy-phenyl)-2-phenylsulfanyl-imidazo-[2,1-b]-thiazole (5a). A mixture of 4-(3,4dimethoxy-phenyl)-5-phenylsulfanyl-thiazol-2-ylamine (3) $(0.01 \mathrm{~mole})$ and phenacyl bromide $(0.01 \mathrm{~mole})$ in anhydrous ethanol $(60 \mathrm{~mL})$ was heated to reflux on a steam bath for $12 \mathrm{hrs}$. Excess of solvent was distilled off and the residue poured into ice cold water $(200 \mathrm{~mL})$ to get crude 6-( $p$-bromo-phenyl)-3(3,4-dimethoxy-phenyl)-2-phenylsulfanyl-imidazo[2,1-b] thiazolium bromide. Neutralisation of above hydrobromide with aqueous sodium carbonate solution afforded the corresponding free base, 6-( $p$-bromo-phenyl)-3-(3,4-dimethoxy-phenyl)-2phenyl-sulfanyl-imidazo[2,1- $b]$ thiazole (5a). They were purified by column chromatography over neutral alumina using benzene-chloroform mixture (95\%: $5 \% \mathrm{v} / \mathrm{v})$ as eluent. Yield $45 \%$, mp $189-191{ }^{\circ} \mathrm{C}$; IR (KBr) vcm ${ }^{-1} 1540,1523,1136 ;{ }^{1} \mathrm{H}$
$\operatorname{NMR}\left(300 \mathrm{MHz}, \mathrm{CDCl}_{3}\right) \delta 3.88\left(\mathrm{~s}, 6 \mathrm{H}, \mathrm{OCH}_{3}\right), 7.23-7.29(\mathrm{~m}$, $8 \mathrm{H}, \mathrm{ArH}), 7.32(\mathrm{~d}, J=7.8 \mathrm{~Hz}, 2 \mathrm{H}, \mathrm{ArH}), 7.51$ (d, $J=8.0 \mathrm{~Hz}, 2 \mathrm{H}$, ArH), 8.04 (s, $\left.1 \mathrm{H}, \mathrm{C}_{5}-\mathrm{H}\right)$. Anal. calcd. for $\mathrm{C}_{25} \mathrm{H}_{19} \mathrm{BrN}_{2} \mathrm{O}_{2} \mathrm{~S}_{2}$ : C, 57.36; H, 3.66; N, 5.35. Found: C, 57.44; H, 3.54; N, 5.49\%.

6-(4-Chloro-phenyl)-3-(3,4-dimethoxy-phenyl)-2-phenylsulfanylimidazo-[2,1-b]-thiazole (5b). Yield 55\%, mp 192 $193{ }^{\circ} \mathrm{C}$; IR (KBr) vcm ${ }^{-1} 1556,1515,1138 ;{ }^{1} \mathrm{H} \mathrm{NMR}(300 \mathrm{MHz}$, $\left.\mathrm{CDCl}_{3}\right) \delta 3.94\left(\mathrm{~s}, 6 \mathrm{H}, \mathrm{OCH}_{3}\right), 7.19-7.32(\mathrm{~m}, 8 \mathrm{H}, \mathrm{ArH}), 7.38$ (d, $J=8.3 \mathrm{~Hz}, 2 \mathrm{H}, \mathrm{ArH}), 7.47$ (d, $J=8.2 \mathrm{~Hz}, 2 \mathrm{H}, \mathrm{ArH}), 8.00$ (s, $\left.1 \mathrm{H}, \mathrm{C}_{5}-\mathrm{H}\right)$. Anal. calcd. for $\mathrm{C}_{25} \mathrm{H}_{19} \mathrm{ClN}_{2} \mathrm{O}_{2} \mathrm{~S}_{2}: \mathrm{C}, 62.68 ; \mathrm{H}, 4.00$; N, 5.85. Found: C, 62.74; H, 3.92; N, 5.94\%.

3-(3,4-Dimethoxy-phenyl)-6-(4-nitro-phenyl)-2-phenylsul fanyl-imidazo[2,1-b]-thiazole (5c). Yield $60 \%$, mp $167-169^{\circ} \mathrm{C}$; IR (KBr) vcm ${ }^{-1} 1544,1528,1132 ;{ }^{1} \mathrm{H} \mathrm{NMR}\left(300 \mathrm{MHz}, \mathrm{CDCl}_{3}\right)$ $\delta 3.95\left(\mathrm{~s}, 6 \mathrm{H}, \mathrm{OCH}_{3}\right), 7.19-7.28(\mathrm{~m}, 8 \mathrm{H}, \mathrm{ArH}), 7.30(\mathrm{~d}, J=8.1$ $\mathrm{Hz}, 2 \mathrm{H}, \mathrm{ArH}), 7.45$ (d, $J=8.1 \mathrm{~Hz}, 2 \mathrm{H}, \mathrm{ArH}), 8.09$ (s, $\left.1 \mathrm{H}, \mathrm{C}_{5}-\mathrm{H}\right)$. Anal. calcd. for $\mathrm{C}_{25} \mathrm{H}_{19} \mathrm{~N}_{3} \mathrm{O}_{4} \mathrm{~S}_{2}$ : C, 61.33; H, 3.91; N, 8.58. Found: C, 61.44; H, 3.89; N, 8.68\%.

2-Benzenesulfonyl-6-(4-bromo-phenyl)-3-(3,4-dimethoxyphenyl)imidazo[2,1- $\boldsymbol{b}]$-thiazole (6a). Yield 50\%, mp 185 - 187 ${ }^{\circ} \mathrm{C}$; IR (KBr) vcm ${ }^{-1} 1533,1933,1171 ;{ }^{1} \mathrm{H}$ NMR $(300 \mathrm{MHz}$, $\left.\mathrm{CDCl}_{3}\right) \delta 3.89$ (s, 6H, OCH3), 7.27-7.33 (m, 8H, ArH), 7.48 (d, $J=8.3 \mathrm{~Hz}, 2 \mathrm{H}, \mathrm{ArH}), 7.58$ (d, $J=8.3 \mathrm{~Hz}, 2 \mathrm{H}, \mathrm{ArH}), 8.01(\mathrm{~s}, 1 \mathrm{H}$, $\left.\mathrm{C}_{5}-\mathrm{H}\right)$. Anal. calcd. for $\mathrm{C}_{25} \mathrm{H}_{19} \mathrm{BrN}_{2} \mathrm{O}_{4} \mathrm{~S}_{2}: \mathrm{C}, 54.06 ; \mathrm{H}, 3.45 ; \mathrm{N}$, 5.04. Found: C, 54.16; H, 3.39; N, 5.15\%.

2-Benzenesulfonyl-6-(4-chloro-phenyl)-3-(3,4-dimethoxyphenyl)imidazo[2,1-b]-thiazole (6b). Yield 41\%, mp 184 - 186 ${ }^{\circ} \mathrm{C}$; IR (KBr) vcm ${ }^{-1} 1525,1320,1177 ;{ }^{1} \mathrm{H}$ NMR (300 MHz, $\left.\mathrm{CDCl}_{3}\right) \delta 3.97\left(\mathrm{~s}, 6 \mathrm{H}, \mathrm{OCH}_{3}\right), 7.22-7.38(\mathrm{~m}, 8 \mathrm{H}, \mathrm{ArH}), 7.48$ (d, $J=8.0 \mathrm{~Hz}, 2 \mathrm{H}, \mathrm{ArH}), 7.60$ (d, $J=8.0 \mathrm{~Hz}, 2 \mathrm{H}, \mathrm{ArH}), 8.04$ (s, $\left.1 \mathrm{H}, \mathrm{C}_{5}-\mathrm{H}\right)$. Anal. calcd. for $\mathrm{C}_{25} \mathrm{H}_{19} \mathrm{ClN}_{2} \mathrm{O}_{4} \mathrm{~S}_{2}$ : C, 58.76; $\mathrm{H}$, 3.75 ; N, 5.48. Found: C, 58.87; H, 3.60; N, 5.58\%.

2-Benzenesulfonyl-3-(3,4-dimethoxy-phenyl)-6-(4-nitrophenyl)imidazo[2,1-b]-thiazole (6c). Yield 60\%, mp 176 - 178 ${ }^{\circ} \mathrm{C}$; IR (KBr) vcm ${ }^{-1} 1537,1333,1164 ;{ }^{1} \mathrm{H}$ NMR (300 MHz, $\left.\mathrm{CDCl}_{3}\right) \delta 3.89\left(\mathrm{~s}, 6 \mathrm{H}, \mathrm{OCH}_{3}\right), 7.32-7.39(\mathrm{~m}, 8 \mathrm{H}, \mathrm{ArH}), 7.51$ (d, $J=7.9 \mathrm{~Hz}, 2 \mathrm{H}, \mathrm{ArH}), 7.68$ (d, $J=7.9 \mathrm{~Hz}, 2 \mathrm{H}, \mathrm{ArH}), 8.05$ (s, $1 \mathrm{H}, \mathrm{C}_{5}-\mathrm{H}$ ). Anal. calcd. for $\mathrm{C}_{25} \mathrm{H}_{19} \mathrm{~N}_{3} \mathrm{O}_{6} \mathrm{~S}_{2}: \mathrm{C}, 57.57$; H, 3.67; N, 8.06. Found: C, 57.66; H, 3.54; N, 8.20\%.

Acknowledgments. This work was supported by Priority Research Centers Program through the National Research Foundation of Korea (NRF) funded by the Ministry of Education, Science and Technology (2009-0094066).

\section{References}

1. Thienopont, D. C.; Vanparijs, O. F. J.; Raeymaekers, A. H. M.; Vandenberk, J.; Demoen, P. J. A.; Allewijn, F. T. N.; Marsboom, R. P. H.; Niemegeers, C. J. E.; Shellekens, K. H. L.; Janssen, P. A. J. Nature 1966, 209, 1084.

2. Andreani, A.; Granaiola, M.; Leoni, A.; Locatelli, A.; Morigi, R.; Rambaldi, M.; Lenaz, G.; Fato, R.; Bergamini, C.; Farruggia, G. J. Med. Chem. 2005, 48, 3085.

3. Andreani, A.; Granaiola, M.; Leoni, A.; Locatelli, A.; Morigi, R.; Rambaldi, M.; Garaliene, V.; Welsh, W.; Arora, S.; Farruggia, G. et al. J. Med. Chem. 2005, 48, 5604.

4. Robert, J. F.; Boukraa, S.; Panouse, J. J.; Loppinet, V.; Chaumont, J. P. Eur. J. Med. Chem. 1990, 25, 731.

5. Andreani, A.; Rambaldi, M.; Leoni, A.; Morigi, M.; Locatelli, A.; 
Georgi, G.; Lenaz, G.; Ghelli, A.; Esposti, M. D. Eur. J. Med. Chem. 1999, 34, 888.

6. Khazi, I. M.; Mahajanshetti, C. S.; Gadad, A. K. Arzneim Forsch. Drug Re. 1996, 46, 949.

7. Khazi, I. M.; Koti, R. S.; Chadha, M. V.; Mahajanshetti, C. S. Arzneim Forsch. Drug Re. 2005, 55, 107.
8. Shetty, N. S.; Koti, R. S.; Lamani, R. S.; Badiger, N. P.; Khazi, I. M. J. Sulf. Chem. 2008, 29, 539.

9. Berlin, K. D.; Herd, M. D. Proc. Okla. Acad. Sci. 1991, 71, 29.

10. Kakarani, H. K.; Kalyani, G. A. Fitoterapia 1984, 55, 232.

11. Winter, C. A.; Risley, E. A.; Nuss, G. W. Proc. Soc. Exp. Biol. 1962, 111, 544. 